\title{
Typhoid Fever in African and Indian Children in Durban
}

\author{
JOAN SCRAGG, CAROL RUBIDGE, and H. L. WALLACE \\ From the Department of Paediatrics and Child Health, University of Natal, Durban, S. Africa
}

Medical literature contains surprisingly few accounts of large series of typhoid fever in children in which such items as severity, response to therapy, complications, and relapse rates are reported in detail.

The purpose of this paper is to present a study of typhoid fever in African and Indian children in Durban, and to review the relevant literature on the subject emanating from other countries.

\section{Material and Method}

The material comprised 316 cases of typhoid fever, all investigated and treated in the paediatric wards of the Department of Paediatrics and Child Health of the University of Natal and King Edward VIII Hospital, Durban, between January 1959 and June 1967 ( $8 \frac{1}{2}$ years).

Table I gives the diagnostic criteria in the 316 children. There was definite clinical evidence of typhoid fever in 298 of these, while 4 were asymptomatic typhoid carriers. A further 7 were 'intravascular shedders' (Watson, 1967) who had no symptoms of typhoid fever but in whom $S$. typhi was isolated on blood culture. Agglutination titres of ' $O$ ' were less than $1 / 25$ in 4 of these children, $1 / 100$ in 1 , and not performed in 2 . We accepted agglutination titres of ' $\mathrm{O}$ ' $1 / 160$ and ' $\mathrm{H}$ ' $1 / 80$ as being significant (Watson, 1955). The remaining 7 children could not have blood culture or agglutination tests performed because of early death, but necropsy confirmed the diagnosis.

\section{Age and Sex Distribution}

Table II shows the age distribution of our 316 children, of whom 163 were male and 153 were female.

Typhoid fever is said to be rare under 2 years of age (Landor, 1941; Watson, 1958; Huckstep, 1962). In our series $27(9 \%)$ were less than $2 . \quad$ Abt and Abt (1966) in a series of 200 children with typhoid fever found only $12(6 \%)$ to be under 2 years of age.

Received July 30, 1968.
Earle (1954) however, reported from Samoa on 30 infants between the ages of 5 weeks and 11 months, the diagnosis of typhoid being made on routine examination of the stools on admission.

\section{Severity}

Table III shows the severity of the disease in this series. We have based our classification of severity on such manifestations as toxaemia, delirium, meningeal irritation, convulsions, etc. Excluding 4 carriers with no constitutional disturbance, 5 in whom the records prevent accurate estimation of severity, and 7 who were regarded as intravascular shedders', $168(56 \%)$ were regarded as severely ill, $113(38 \%)$ as moderately ill, and $19(6 \%)$ as mildly ill.

TABLE I

Diagnostic Criteria in 316 Cases of Typhoid

\begin{tabular}{c|c|c|cc}
\hline $\begin{array}{c}\text { No. of } \\
\text { Cases }\end{array}$ & $\begin{array}{c}\text { Blood } \\
\text { Culture } \\
\text { Positive }\end{array}$ & $\begin{array}{c}\text { Widal } \\
\text { Significant }\end{array}$ & $\begin{array}{c}\text { Stool } \\
\text { Culture } \\
\text { Positive }\end{array}$ & $\begin{array}{c}\text { Urine } \\
\text { Culture } \\
\text { Positive }\end{array}$ \\
\hline 286 & 207 & 229 & 37 & 17 \\
6 & 6 & ND & 2 & 1 \\
6 & ND & 4 & 5 & 2 \\
$4^{\star}$ & ND & ND & 4 & 0 \\
$7 \dagger$ & 7 & 0 & 0 & 0 \\
$7 \ddagger$ & ND & ND & ND & ND \\
\hline 316 & 220 & 233 & 48 & 20 \\
\hline
\end{tabular}

* Asymptomatic carriers.

† Intravascular shedders.

$¥$ Confirmed at necropsy.

ND, Not done.

TABLE II

Age Distribution

\begin{tabular}{c|c|c|c|c|c|c|c|c}
\hline Age (yr.) & $0-1$ & $1-$ & $2-$ & $3-$ & $4-$ & $5-$ & $>6$ & $\begin{array}{c}\text { All } \\
\text { Ages }\end{array}$ \\
\hline No. of cases & 11 & 7 & 9 & 19 & 29 & 34 & 207 & 316 \\
\hline
\end{tabular}


There is considerable divergence of opinion regarding the severity of typhoid fever in infants and young children. For example, Watson (1958) and Ashcroft (1964) believe it to be a mild disease, and this opinion is supported by Bauer and Bower (1951). However, as long ago as 1903 Koplik stated that erroneous ideas existed with regard to typhoid fever in the very young. He pointed out then that the mortality under 2 years was speculative because of unreliable statistics, and stressed that serious complications in children did occur, and that the disease was not necessarily milder than in adults. Huckstep (1962) too indicated that occasionally in children it is severe, and that in young infants the mortality rate is high.

\section{Duration of History}

In children the onset is often sudden, resembling other acute diseases.

Table IV shows the duration of symptoms before admission, the range being 1-90 days (mean 8 days). In our group of infants under 2 years of age the duration of symptoms was not significantly shorter than in the older child.

\section{Diagnosis}

Sood and Taneja (1961a) believed that there was no typical clinical picture of typhoid fever in children, and Pohowalla (1965) stated that as a rule the classical features of this disease described in textbooks were absent in children. Nevertheless, in this series the correct diagnosis of typhoid fever was made by the admitting officer in $66 \%$ of cases, though a family history did aid in the diagnosis in a few instances. Conditions which sometimes posed a diagnostic difficulty were bronchopneumonia, gastro-enteritis, meningitis, encephalitis, and tuberculosis. Typhoid fever was an unexpected finding in 3 infants at necropsy.

\section{Clinical Features}

Table $\mathrm{V}$ indicates the frequency of major and other manifestations in this series. A few cases have had to be excluded owing to incomplete or lost records, etc. The 'intravascular shedders', asymptomatic typhoid carriers, and 9 cases in which no history was obtainable, are also excluded.

The most constant finding, as would be expected, was fever, which was present in $99 \%$. Our experience was similar to that of Watson (1955) and Ikeme and Anan (1966) who found that the stepladder pattern described by Huckstep (1962) was rarely seen. Pyrexia of sustained or intermittent type was common.
TABLE III

Severity in 316 Cases of Typhoid

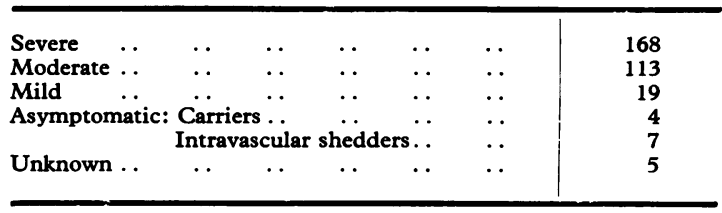

TABLE IV

Duration of History

\begin{tabular}{llllll|r}
\hline 7 days or less & $\ldots$ & $\ldots$ & $\ldots$ & $\ldots$ & $\ldots$ & 77 \\
8-13 days . & $\ldots$ & $\ldots$ & $\ldots$ & $\ldots$ & $\ldots$ & 150 \\
14 days or more & $\ldots$ & $\ldots$ & $\ldots$ & $\ldots$ & $\ldots$ & 56 \\
Unknown . & $\ldots$ & $\ldots$ & $\ldots$ & $\ldots$ & $\ldots$ & 18 \\
No complaints & $\ldots$ & $\ldots$ & $\ldots$ & $\ldots$ & $\ldots$ & 8 \\
Intravascular shedders & $\ldots$ & $\ldots$ & $\ldots$ & $\ldots$ & 7 \\
\hline
\end{tabular}

Headache, an uncommon symptom in childhood, occurred frequently in these children. Excluding the 27 young infants who would naturally not complain of this, headache was present in 157 (58\%). Reports on the incidence of headache are conflicting. Watson (1958) states that the main complaint is always headache, but Sood and Taneja (1961a, b) found this symptom in only $8 \%$ and $3 \%$ respectively of their two series. Cough was a complaint in 142 $(48 \%)$. This was accompanied by signs of bronchitis in $33 \%$.

There was a history of diarrhoea at the onset of the illness in $137(46 \%)$. Because this complaint is so prevalent in infants and small children, the

TABLE V

Clinical and Haematological Manifestations

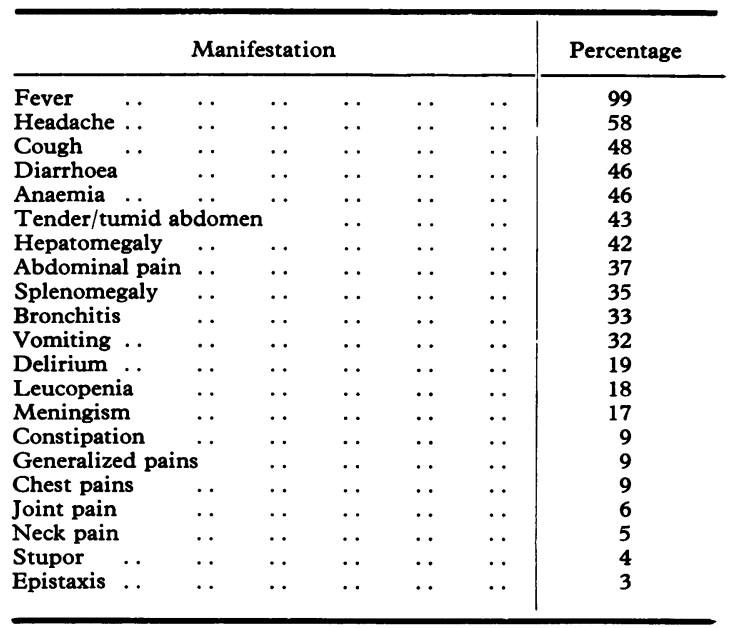


diagnosis of typhoid fever may be missed or delayed. In fact this occurred on 10 occasions when an incorrect diagnosis of gastro-enteritis was made on admission. These findings regarding incidence of diarrhoea compare with those of the Aberdeen study in children (Galloway, Clark, and Blackhall, 1966), in which $36 \%$ had diarrhoea in contrast to only $17 \%$ in the New Delhi study of Sood and Taneja (1961a).

Abdominal pain as an early complaint occurred in $100(37 \%)$, an incidence almost identical with that in the Aberdeen series ( $36 \%$ ). On the other hand, vomiting was less prevalent $(32 \%$, as compared with $49 \%$ ).

In 129 instances (43\%), a tender, tumid abdomen was present. In children the importance of the tumid or 'doughy' abdomen has been stressed as an early diagnostic sign (Feldman and Selby, 1950). Sood and Taneja (1961a), however, found abdominal tumidity in only $11 \%$ of their childhood cases.

Hepatomegaly was noted in $125(42 \%)$. In the majority there was no explanation for this finding. Hepatomegaly was a feature of $25 \%$ of Stuart and Pullen's (1946) 360 cases. Splenomegaly was found in only 106 cases (35\%). Huckstep (1962) considered that in children the spleen was practically always enlarged, soft, and tender, and should be regarded as a more valuable diagnostic sign than in adults. Friedman (1954) found a palpable spleen in $68 \%$ of the children he studied. In most of the other childhood series splenomegaly has been reported in about 30-40\% (Sood and Taneja, 1961a; Galloway et al., 1966).

\section{Urinary Findings}

Albuminuria, usually transient, occurred in 102 cases $(42 \%)$, and pyuria in $67(28 \%)$. Albuminuria and pyuria occurring apart from the renal complications of typhoid fever have been reported fairly frequently (Blumer, 1895; Patch, 1925; Rolleston and Ronaldson, 1940; Huckstep, 1962).

\section{Haematological Findings}

Leucopenia. White blood cell counts were studied in 298 children. A count of less than 5000 per cu.mm. was found in only $53(18 \%)$. In a further 53 the count was greater than 10,000 per cu.mm. (mean 8000 per cu.mm.). The absence of leucopenia in children has been commented upon by Bauer and Bower (1951) who found that a normal or high white blood cell count was one of the main reasons for delayed diagnosis.

Anaemia. Full blood counts were carried out in 296 children, and 136 (46\%) were found to have
$\mathrm{Hb}$ of $10 \mathrm{~g} . / 100 \mathrm{ml}$. or less on admission; $41 \mathrm{had}$ levels of less than $8 \mathrm{~g} . / 100 \mathrm{ml}$. Repeated blood studies showed a further fall in $\mathrm{Hb}$ in 83 during the course of the illness.

The length of the history before admission could be correlated with the lowest $\mathrm{Hb}$ levels, but it was not possible to correlate $\mathrm{Hb}$ levels and nutritional status.

Stuart and Pullen (1946) and Lien-Keng and Odang (1959) observed that in adults and children anaemia was common in typhoid fever, that it could develop relatively rapidly, and was sometimes profound. In the Indian childhood study (Sood and Taneja, 1961a) $53 \%$ were found to be anaemic.

Thrombocytopenia. Reduction of platelets was reported in $67(23 \%)$ children, of whom 3 showed evidence of bleeding and died. At necropsy bronchopneumonia was found in all 3, and in 1 of these hepatitis was also present.

Drummond (1943) reported a constant and marked fall of thrombocytes in all his cases of typhoid fever. However, Hirsowitz and Cassel (1951) studied 18 cases of typhoid fever and were unable to confirm this finding. Lien-Keng and Odang (1959) reported a moderate thrombocytopenia in $24 \%$ of their cases.

\section{Neurological Manifestations}

A number of neurological manifestations of typhoid fever have been described, some of which are commonly found while others occur only rarely.

Delirium. Delirium was a feature in 58 children $(19 \%)$, and was normally of short duration but occasionally persisted for a week or more. The apathy and dullness described in adults with typhoid fever were conspicuously absent in our young children.

Stupor. 11 children presented in a stuporous state, necessitating many investigations to establish the cause.

Meningeal irritation. As in other infections in childhood, meningism may occur at the onset of the illness, and in our study $51(17 \%)$ had this type of presentation, which made it sometimes difficult to exclude meningitis during the first few days. Lumbar punctures were performed on 91 children. In the majority this was because of meningeal irritation while, in the remainder, convulsions, coma, ataxia, etc. were the reasons. The CSF, however, was normal in all but 9 cases.

This 'meningeal' type of onset is more commonly 
found in children (Smith, 1911; Rolleston and Ronaldson, 1940; Boquien and Grislain, 1949; Feldman and Selby, 1950; Scott, Banks, and Crawford, 1950; Huckstep, 1962). The French writers have described these cases as 'meningotyphoid'. Barglow (1957) and Abt and Abt (1966) stated that the underlying typhoid infection might be completely concealed by the nervous manifestations dominating the clinical picture.

There was a wide variety of less common symptoms that occurred in this series (Table V). Complaint of pain localized to joints, chest, neck, etc. occasionally delayed diagnosis by directing attention to other systems. Constipation was unusual, and this has been the experience of others reporting on children (Sood and Taneja, 1961a; Galloway et al., 1966). In keeping with other studies in children (Bauer and Bower, 1951; Earle, 1954; Abt and Abt, 1966), we also found epistaxis to be a rare complaint $(3 \%)$.

The frequently described bradycardia in adults with typhoid fever appears to be rare in children (del Negro, 1962; Huckstep, 1962), and this was our experience, as we encountered it on only 2 occasions.

There was not a single instance of rose spots among our 316 African and Indian children. In white-skinned children rose spots may be a valuable diagnostic sign (Smith, 1911; Griffith, 1912; Friedman, 1954; Huckstep, 1962; Galloway et al., 1966), but on dark-skinned patients rose spots are either absent or invisible.

Group infection. Multiple family group infection involving parents, sibs, or both parents and sibs occurred on 31 occasions.

\section{Respiratory Complications}

Clinical and radiological pneumonia was found in $35 \%$ of the children. These findings are in accordance with those of Huckstep (1962) and Abt and Abt (1966) who found bronchopneumonia a common complication of typhoid fever in children. Lung abscess and/or empyema have been reported in typhoid fever (Smith, 1911; Rolleston and Ronaldson, 1940; Minor and White, 1946; Prabhu, 1955; Ikeme and Anan, 1966). We encountered each of these complications on one occasion only.

\section{Neurological Complications}

Convulsions. We regarded convulsions as a complication rather than as a manifestation of typhoid fever.

In this series 15 children had one or more convulsive attacks (Table VI). The CSF was normal in all but 3 . In the young the disease sometimes begins acutely with high temperature and a convulsive seizure. This does not necessarily indicate a bad prognosis. On the other hand, convulsions late in the disease are usually of grave import, indicating as a rule an organic brain lesion.

Osler $(1895 \mathrm{a}, 1906)$ reported convulsions as a complication of typhoid fever. Other authors have noted this as a rare occurrence (Marmion, 1952; Barglow, 1957; Abt and Abt, 1966), and agree that when convulsions do occur it is usually in children.

Aphasia. We have tended to use the term mutism for the children who would not, or could not, talk. This mute state occurred in 9 children $(3 \%)$. Only one was associated with hemiplegia, the latter being left-sided. This child remained mute for 8 weeks but made a complete recovery. Examples of aphasia unassociated with hemiplegia in the course of typhoid fever in children have been reported by Olser (1895a), Smith (1911), Pohowalla and Ghai (1957), and Pohowalla (1965). The nature of the lesion responsible for the aphasia is not known but it has been postulated that it is an encephalitis.

Ataxia. 8 children exhibited ataxia. In all but one instance the ataxia was cerebellar in type.

TABLE VI

Neurological Complications Among 316 Cases of Typhoid

\begin{tabular}{|c|c|c|c|c|c|c|}
\hline Convulsions & $\ldots$ & $\ldots$ & $\ldots$ & $\ldots$ & . & 15 \\
\hline Aphasia/mutism & $\ldots$ & . & . & $\ldots$ & .. & 9 \\
\hline Ataxia $\quad \ldots$ & $\ldots$ & .. & . & . & .. & 8 \\
\hline Hemiplegia & . & . & .. & . & .. & 2 \\
\hline Facial nerve pals & & . & . . & . & .. & 2 \\
\hline Meningitis & . & . & . & . & .. & 1 \\
\hline Cerebellar haem & orrhage & . & . & . & . & 1 \\
\hline Peripheral neurit & & . & $\ldots$ & $\ldots$ & $\ldots$ & 1 \\
\hline
\end{tabular}

Study of the literature reveals that ataxia must be rare in typhoid fever. The only reference we have been able to find is a paper by Marie (1884) who stated that occasionally ataxia occurred in this disease. Choreiform movements have been described in a few children suffering from typhoid fever (Feldman and Selby, 1950; Pohowalla and Ghai, 1957; Sood and Taneja, 1961a), but ataxia as such is not mentioned. We feel that when ataxia does occur it is probably indicative of typhoid encephalitis.

Hemiplegia. This rare complication occurred only twice in our study. One child had repeated convulsions on admission and developed a left-sided 
hemiplegia 22 days later. He recovered completely. The other example of hemiplegia also followed convulsions, but this infant was left with residual weakness. Hemiplegia has been reported in children as a rare finding by Sen (1946), Schachter (1954), and Abt and Abt (1966). Smithies (1907) collected 42 cases of this complication, in 9 of which the hemiplegia was preceded by convulsions: 10 of the total were children under 12 years. According to reports hemiplegia has usually occurred between the second and fourth week, or has followed upon convulsions. From necropsy studies thrombosis has been the commonest lesion.

Facial nerve palsy. This rare complication occurred only twice, once in a child with proved typhoid meningitis. The only reference to this which we found was that of Schachter (1954) who described facial palsy in a 4-year-old child with typhoid encephalitis. Sen (1946) has observed fifth and eighth nerve involvement but not seventh nerve palsy as a complication of typhoid fever.

Peripheral neuritis. One child had evidence of peripheral neuritis. Huckstep (1962) in the course of his extensive experience encountered peripheral neuritis in only 8 cases. Most other authors have reported this in only 1 or 2 cases (Rolleston and Ronaldson, 1940; Marmion, 1952; Thanawala, 1955).

Cerebral haemorrhage. One case in our series had evidence of cerebellar haemorrhage at necropsy. There have been reports of isolated examples of intracranial haemorrhage as a complication of typhoid fever. Sen (1946) reported 2 cases of pontine haemorrhage.

Encephalitis. This is a difficult diagnosis to make with certainty. If our patients with aphasia and ataxia are included, then $20(1 \%)$ children could be classified as probable examples of encephalitis. In 8 of these the CSF revealed a mild to moderate pleocytosis and 1 showed a slight protein increase. Cultures were all sterile. These children exhibited a variety of neurological signs such as aphasia, ataxia, convulsions, with or without meningism, prolonged stupor, mental changes, nystagmus, etc. Only 1 died, an infant of 13 months. None of the children who recovered had any sequelae.

Typhoid encephalitis has been regarded as a very unusual complication (Wieland, 1930; Rolleston and Ronaldson, 1940; Sulakhe, 1941; Roger and Gastaut, 1945; Sen, 1946). However, Landor (1941) reported clinical evidence of encephalitis in many of his cases of typhoid fever in Singapore. In his experience the CSF was usually normal. Joshi (1963) found encephalitis to be the commonest of all the complications in his series of typhoid fever, occurring in 15 of 111 cases. In all but 2 the CSF showed a moderate pleocytosis and rise in protein.

Some authors have designated such cases as encephalopathy (Friedman, 1954; Zellweger and Idriss, 1960; Jaffe, 1966). Basing their diagnosis on disturbance of consciousness, convulsions, meningism, aphasia, etc., Pohowalla and Ghai (1957) reported 13 of 155 children as examples of typhoid encephalopathy; CSF was normal in all but 2 . They stressed the grave prognosis, since 2 died and 6 were left with permanent cerebral sequelae.

Meningitis. This extremely serious and rare complication occurred in one case. The diagnosis was proved by culturing $S$. typhi from the CSF. This girl recovered but was left with slight athetosis affecting her hands.

Meningitis due to an organism of the genus salmonella is said to be four times as frequent in children as in adults (Beene, Hansen, and Fulton, 1951). The earliest review on the subject of typhoid meningitis was that of Cole (1904) in which he collected 13 proved cases. Since then a number of authors have reported on isolated examples of this complication, among whom are the following: Henry and Rosenberger, 1908; Lavenson, 1908; Symmers and Wilson, 1909; Bayne-Jones, 1917; Baumgartner and Olsen, 1920; Dukakis, 1927; Jáureguy, 1927; Schweisgut, 1927; Dworecki, 1934; Lantin and Morales, 1938; Dérot and Maschas, 1938; Hageman, 1938; Gurevitch, 1945; Stuart and Pullen, 1946; Stuart, 1948; Kao, 1948; Ripy, 1950; Friedman, 1954; Rowland, 1961; Huckstep, 1962.

\section{Gastro-intestinal Complications}

Intestinal perforation and haemorrhage. Perforation occurred in $12(4 \%), 6$ of whom died. 4 of these children underwent laparotomy and 3 died. Of the 8 who were treated conservatively, 5 died. Necropsy was carried out on 7 and showed typhoid ulceration of the ileum, perforation, and general peritonitis. The child in whom no necropsy was undertaken had a laparotomy 4 days after admission, developed bronchopneumonia, and died 10 days later.

Six $(2 \%)$ developed intestinal haemorrhage, 3 of whom died; 2 of the fatal cases developed perforation and peritonitis before death.

In children intestinal perforation has been reported as a rare event (Harries and Mitman, 1951; Friedman, 1954; Huckstep, 1962; Pohowalla, 1965; Abt and Abt, 1966). However, del Negro (1962) 
reported this in $10 \%$ and Lozoya (1948) in $7 \%$ of their studies in children. Rolleston and Ronaldson (1940) and Pohowalla (1965) were of the opinion that death due to intestinal haemorrhage or perforation was rare in children, because anatomically the disease differs from that in later life in that ulceration of Peyers patches is as a rule much more superficial, if it occurs at all. Our experience does not support this view, as intestinal haemorrhage and perforation occurred as often in our children as that reported in many adult series; and in 19 cases at necropsy 16 showed obvious intestinal ulceration, 7 of which had perforated.

The mortality rate from intestinal haemorrhage in adults is variously reported as $10-100 \%$ (Lantin and Ignacio, 1929; Rajoo, 1942; Patel, Banker, and Modi, 1954; Thanawala, 1955; Prabhu, 1955; Vaizey, 1959; Joshi, 1963; Pathania and Sachar, 1965). A similar variation in the mortality rate from perforation is found. Our mortality rates of $50 \%$ and $66 \%$, respectively, for intestinal haemorrhage and perforation are comparable with the reported findings in adults.

\section{Hepatic Complications}

Jaundice. This was apparent in 3 children on admission, and a further 6 developed this during the first week in hospital. All had enlarged livers. Liver function tests carried out in 7 of these 9 children were indicative of hepatitis. A further 4 had tender hepatomegaly and evidence of abnormal liver function tests, but no clinical jaundice. One other child, who had abnormal liver function tests in the absence of hepatomegaly or jaundice, died, and necropsy revealed hepatic necrosis. There was one case which was shown to have pyaemic liver abscesses at necropsy.

Osler and McCrae (1920) reported that slight icterus was not uncommon, but jaundice of marked degree was found by them in only 8 of 1500 cases of typhoid fever. Other authors have reported that jaundice is an unual finding (Lantin and Ignacio, 1929; Stuart and Pullen, 1946; Friedman, 1954).

\section{Cardiovascular Complications}

In this study repeated recording of blood pressure was not done except in a few cases where this was deemed necessary. ECG studies were only done when indicated.

We regarded 10 children ( $3 \%$ ) as having cardiovascular complications. 5 were admitted in congestive cardiac failure, 3 of whom showed ECG changes compatible with myocarditis. Three others devel- oped triple rhythm; in only one of these was the ECG recorded and this was normal.

A further 2 children deserve comment.

(i) One (Case 19, see Table VIII) with established mitral stenosis due to previous rheumatic carditis, had a positive blood culture and highly significant agglutination titres. Death occurred from congestive cardiac failure, and necropsy revealed subacute bacterial endocarditis of the mitral valve. Bacterial culture of gall-bladder contents yielded $S$. typhi, but attempted culture of mitral vegetations was unsuccessful.

(ii) Another child, who died, age 6 years (Case 15, Table VIII), was classified as an 'intravascular shedder'. Blood culture was positive but the agglutination titre was only ' $O$ ' $1 / 100$. At necropsy mitral valve vegetations were present, the aetiology of which was not definitely established, though the histology was not that of rheumatic endocarditis.

\section{TABLE VII}

Mortality Among 316 Cases of Typhoid

\begin{tabular}{c|c|c}
\hline Age (yr.) & No. of Deaths & Percentage \\
\hline $0-1$ & 3 \\
$13 / 12-23 / 12$ & 1 \\
2 & 3 \\
3 & $\begin{array}{r}4 \\
4\end{array}$ & 27 \\
5 & 11 \\
6 & 23 & 25 \\
\hline Total & 6 \\
\hline
\end{tabular}

Some adult electrocardiographic studies have revealed changes in about $50 \%$, and toxic myocarditis is said to be common (Mainzer, 1947; Rachmilewitz and Braun, 1948; Eliakim, 1960). We have not found reference to this in childhood apart from Rowland (1961) who noted myocarditis in 9 children, 6 of whom were under 12 years of age.

\section{Renal Complications}

Acute nephritis. $8(3 \%)$ children presented with a clinical picture of acute nephritis, the diagnosis being supported by study of the urine, blood urea, etc. These children, all of whom recovered, undoubtedly had typhoid fever, but whether the acute nephritis was due to typhoid or was poststreptococcal in origin was impossible to say. One of the 8 did have a history of sore throat and 2 had evidence of impetiginized skin lesions, a common precursor to the numerous cases of acute nephritis in children which come under our care.

Rolleston and Ronaldson (1940) pointed out that when acute nephritis did occur in the course of typhoid fever it in no way differed from that seen in other infections. Most authors agree that this is a 
rare complication (Osler and McCrae, 1920; Rolleston and Ronaldson, 1940; Huckstep, 1962).

Lantin and Ignacio (1929) in a predominantly adult study encountered this complication in 39 out of 3255 cases, with a mortality of $23 \%$.

Pyelonephritis. In 2 of the children who died necropsy revealed focal interstitial pyelonephritis.

\section{Haematological Complications}

Haemolytic anaemia. Two children on admission appeared to have a blood picture compatible with haemolytic anaemia. They had severe anaemia, reticulocytosis, and suggestive morphological appearance of the peripheral blood. Unfortunately, however, neither was sufficiently well investigated to warrant a firm diagnosis of haemolytic anaemia.

Since Osler (1895b) first recorded haemolytic anaemia as a rare finding in typhoid fever, there have been several reports of this complication (Berman, Braun, and Rachmilewitz, 1945; Wright, 1945; Batty Shaw, 1951; McFadzean and Choa, 1953; Ruggieri, 1961; Huckstep, 1962; Retief and Hofmeyr, 1965). Haemolysis in typhoid fever in children with G6PD deficiency has recently been reported by Hersko and Vardy (1967). These authors felt that it was the disease process and not the therapy which was the operative factor.

Haemoglobinuria. This complication occurred only once. A severely ill child of 6 years was found on admission to have $\mathrm{Hb} 8.2 \mathrm{~g} . / 100 \mathrm{ml}$, WBC 5000/cu.mm. and reduced platelets. The following day she developed haemoglobinuria and $\mathrm{Hb}$ fell to $6.9 \mathrm{~g} . / 100 \mathrm{ml}$. This occurred before the start of chloramphenicol therapy. She made an uneventful recovery.

Friedman (1954) found acute haemolysis with haemoglobinuria to be the commonest of all complications, occurring in no fewer than 11 of 244 children with typhoid fever in Israel. Chloramphenicol could not be incriminated, as in the majority haemolysis was evident on admission. This finding is remarkable in view of the rarity of this complication reported from other sources. Wright (1945), Batty Shaw (1951), McFadzean and Choa (1953), and Smith (1951) recorded haemoglobinuria in which chloramphenicol was the probable causative factor.

Arthritis. The only other complication that arose in our series was arthritis. We encountered 3 examples of this. One child had a swollen tender knee on admission, another a painful swollen wrist 20 days after admission, and the third developed arthritis of the right hip joint some weeks after apparent recovery from very severe typhoid fever. The 2 former children recovered completely, but the outcome in the third child is unknown.

Most authors who have reported on this have encountered only one or two cases of arthritis (Gupta, 1942; Top, 1947; Vaizey, 1959; Rowland, 1961).

\section{Treatment}

Chloramphenicol therapy was employed in 289 of the 316 cases: 27 did not receive chloramphenicol for various reasons. The usual dose given was $\mathbf{5 0}$ $\mathrm{mg} . / \mathrm{kg}$., and the drug was usually continued for 21 days.

The response to treatment with chloramphenicol was satisfactory in 262 children or $91 \%$. The remaining $27(9 \%)$ failed to respond, and 10 of these children died. Of the 17 survivors, 13 responded well to treatment with ampicillin.

The lack of response in $27(9 \%)$ is exactly similar to the experience of Watson (1954) who, in a study of 110 cases in this area, found that $9 \%$ showed only poor response to chloramphenicol, or failed to respond at all, and of Friedman (1954) who found a similar lack of response in $8 \%$ of the children in his study in Israel.

Only 5 of our children or $2 \%$ of the total, relapsed. The time intervals after completion of chloramphenicol therapy and relapse were $3,6,19$, 29 , and 98 days, respectively. The evidence for diagnosis of relapse was a recurrence of symptoms and re-isolation of $S$. typhi. 2 of the 5 had received full doses of chloramphenicol. 2 responded to a second course of chloramphenicol and 3 responded to ampicillin.

It is obvious from the voluminous literature on the subject that while chloramphenicol has constituted a major advance in treatment in that it cuts short the disease, it has failed to reduce the relapse rate, the incidence of complications, or the carrier state. In fact, since the advent of chloramphenicol much evidence has accumulated to suggest that cases treated with this drug show a higher relapse rate than those untreated (Le Riche and Peacock, 1951; Huckstep, 1962; Lantin, Geronimo, and Calilong, 1963). It is also apparent that relapse depends on duration of therapy rather than on the actual dose of chloramphenicol employed.

There is little doubt that chloramphenicol given for periods of less than 10 days results in a high relapse rate, sometimes even up to $50 \%$ (Woodward et al., 1948; Woodward, Smadel, and Ley, 1950; Smadel, Woodward, and Bailey, 1949; Smadel, Bailey, and Lewthwaite, 1950; Edge, 1950; El Ramli, 1950, 1953; Good and Mackenzie, 1950; 
Rankin and Grimble, 1950). Huckstep (1962) found that if chloramphenicol was given for 15 days the relapse rate was only $28 \%$ as compared with $41 \%$ when given for 10 days or less. He advocated that it should be given for at least 14 days. However, Campbell (1966) found a relapse rate as high as $30 \%$ when this drug was employed for 12-15 days. Watson $(1954,1957)$ reported a relapse rate of only $6 \%$ when chloramphenicol was given for 10-12 days after defervescence, which means that the total duration of the course would be nearer 18-21 days.

In children there are few large series from which comparison of relapse rates can be made. Friedman (1954) found the relapse rate under 4 years of age to be $22 \%$ and over 4 years it was only $9 \%$. This has not been our experience, since 3 of the 5 children who relapsed in this series were 8 years old. Sood and Taneja (1961b) reported a relapse rate in $15 \%$ of 33 children up to 12 years studied by them in India. By comparison our relapse rate is extremely low. It has been our policy for some years now to give chloramphenicol for 21 days, irrespective of how soon the children become afebrile, and we believe that this is the probable explanation for the low relapse rate.

\section{Carrier State}

Four children were referred for admission by Public Health authorities as asymptomatic typhoid carriers. Two had S. typhi in both stool and urine, one was a 'stool carrier' and another a 'urinary carrier'.

We have no long-term follow-up of the children discharged apparently well and in whom repeated stool and urine cultures were done following cessation of therapy. Thus, we cannot determine the possible carrier rate of our symptomatic cases.

\section{Mortality}

Twenty-three children died ( $7 \%$ ) (Table VII), 9 of the deaths occurring within 48 hours of admission. The mortality of infants under 1 year was $27 \%$, for the group $1-2$ years $25 \%, 3-5$ years $6 \%$, and 6 years and over, $5 \%$.

It is interesting to compare mortality rates given in early reports before chloramphenicol was available with those since 1948 when the drug was introduced.

Osler (1895a) reported a mortality of $9 \%$ among 1500 cases, Lantin and Ignacio (1929) a rate of $19 \%$ and Minchin (1939) one of $14 \%$. Rolleston and Ronaldson (1940) showed a striking reduction in mortality from $16 \%$ in the period $1870-1913$, to $6 \%$ in 1929-37 before the advent of chloramphenicol.
Lantin, Gamboa, and Sadili (1951) showed a fall in mortality from $50 \%$ before the use of chloramphenicol, to $26 \%$ after its introduction, and in a later study (1963) this same author reported a further reduction to $8 \%$. Similarly, Vaizey (1959) experienced a reduction from $25 \%$ before chloramphenicol to $8 \%$ with its use. Bearing in mind the falling death rate in typhoid fever before the introduction of chloramphenicol, the reported decline since its advent is probably not entirely due to the antibiotic but, in part, due to improvement of supportive measures and management of complications. However, there remains a striking variation in mortality rates in typhoid fever treated with chloramphenicol. These vary from as little as $1 \%$ (Marmion, 1952; Woodward, Smadel, and Parker, 1954) to as high as 24\% (Musoke, 1952; Ikeme and Anan, 1966). This may well be due to variation in the severity of the disease in different parts of the world.

There is a difference of opinion with regard to the mortality of this disease in children. Some have stated that the mortality rate is lowest in children, while others believed it to be highest in the young. Smith (1911) reported a rate of $7 \%$ and Herderschêe (1927) a rate of $2 \%$ in children under 5 , and $4 \%$ in the 5-10 years age-groups. Rolleston and Ronaldson $(1940)$ found the lowest mortality $(6 \%)$ in the 5-10 years age-group, and Friedman (1954) reported rates of $3 \%$ in chloramphenicol treated and $4 \%$ in untreated children. Similarly, del Negro (1962) and Ashcroft (1962) found rates of $7 \%$ and $4 \%$, respectively, among children they studied. On the other hand, Ikeme and Anan (1966) explained their high over-all mortality of $24 \%$ on the greater mortality in patients under 10 years of age, which was $44 \%$.

The over-all mortality of only $7 \%$ in the present series does not suggest that children are specially at risk in this disease except in the very young agegroup of under 2 years.

\section{Necropsy Findings}

The findings at necropsy in 19 of the 23 deaths are shown in Table VIII.

\section{Discussion}

Durban and its environs falls into 'the mixed standard of hygiene' mentioned by Ashcroft (1964), and in this endemic area the disease is common in the non-White community and affects all agegroups.

Unlike the experience of some authors reporting from other countries, we do not regard typhoid fever in childhood as a mild disease of shorter duration, 
TABLE VIII

Necropsy Findings

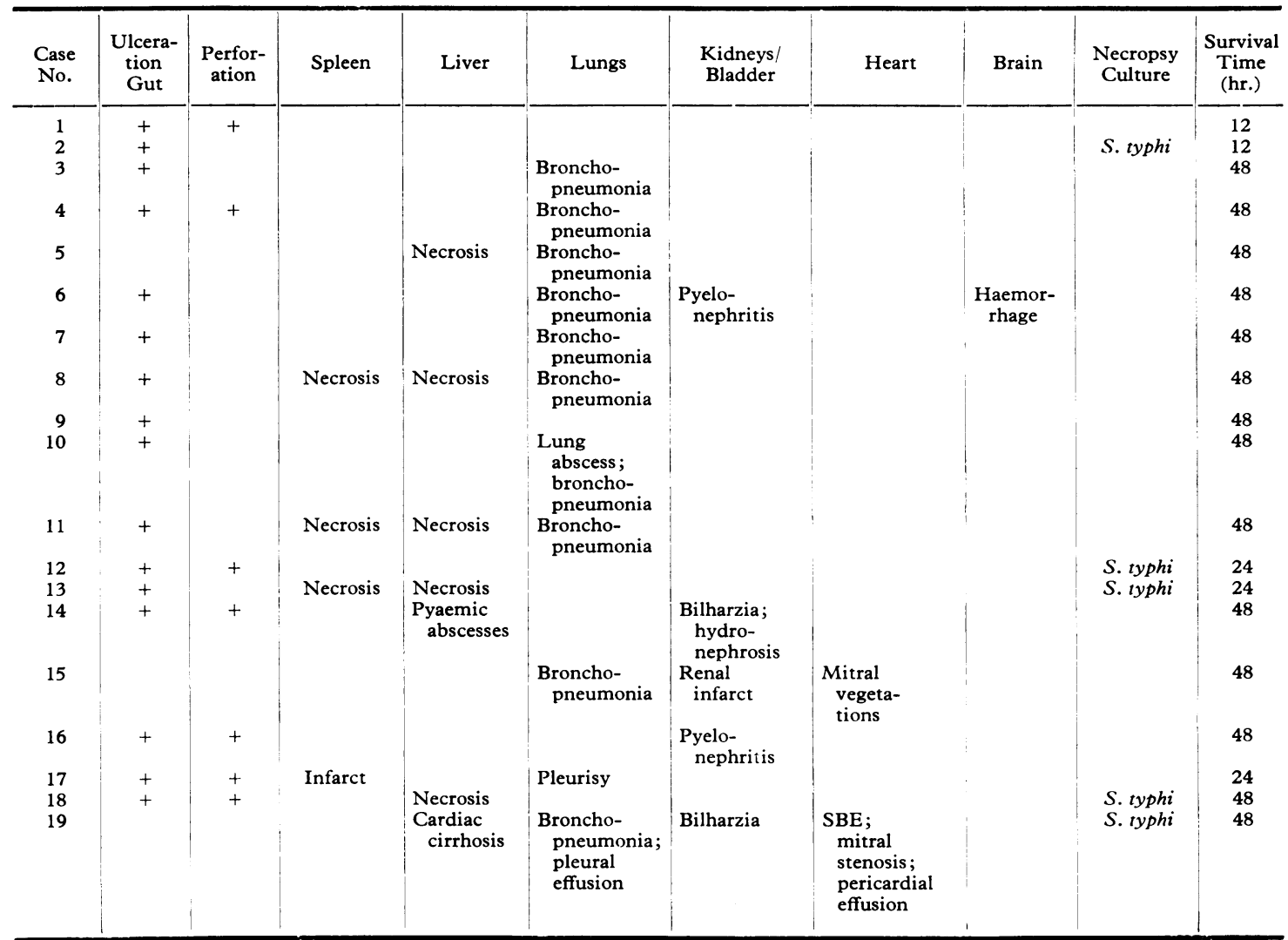

SBE $=$ Subacute bacterial endocarditis.

as the majority of our children were severely ill and the course of the illness was no shorter than usual.

As a result of a careful study of the literature on typhoid fever, it is evident that there is wide variation in symptomatology, incidence of complications, mortality, etc. in different parts of the world. Whether this is due to differences in severity of infection or to varying degrees of susceptibility to the organism of population groups in different areas is difficult to say. Possibly both factors play a part.

From some areas it has been reported that the classical features of typhoid fever are absent in children, with resulting difficulty in diagnosis. This has not been our experience as a probable diagnosis of typhoid fever was made on admission in two-thirds of the cases. It is acknowledged, however, that diagnosis may be difficult in very young children.
The manifestations of the disease in children were found to be essentially similar to those in adults, with minor variations. The time-honoured and oft-described splenomegaly and leucopenia were not prominent in this series, and could not be regarded as of any real diagnostic value.

The over-all mortality of $7 \%$ in our African and Indian children compares favourably with that of children in other countries. This relatively low mortality rate is difficult to explain, since the majority of the children in the series were malnourished, and one would expect a high mortality.

The immediate efficacy of chloramphenicol therapy was similar to that reported elsewhere, but the relapse rate was considerably lower than in many other series. This may be due to our policy of continuing chloramphenicol therapy in full doses for 21 days irrespective of the apparent rapidity of response. 


\section{Typhoid Fever in African and Indian Children in Durban}

\section{Summary}

A comprehensive study is presented of 316 cases of typhoid fever occurring in African and Indian children in the Durban area between January 1959 and June 1967.

The relevant literature pertaining to typhoid fever in children has been reviewed.

We wish to thank Dr. H. R. J. Wannenburg, Medical Superintendent, King Edward VIII Hospital, Durban, for facilities.

\section{REFERENCES}

Abt, I. A., and Abt, A. F. (1966). Typhoid fever. In Brennemann's Practice of Pediatrics, Vol. 2, ch. 30. W. F. Prior Company, Hagerstown, Maryland.

Ashcroft, M. T. (1962). The morbidity and mortality of enteric fever in British Guiana. W. Indian med. f., 11, 62.

(1964). Typhoid and paratyphoid fevers in the tropics. 7. trop. Med. Hyg., 67, 185 .

Barglow, D. R. (1957). Typhoid fever. In Tice's Practice of Medicine, Vol. 4, p. 459. W. F. Prior, Hagerstown, Maryland.

Batty Shaw, A. (1951). Haemoglobinuria in typhoid fever. Report of two cases. Lancet, $2,813$.

Bauer, F. K., and Bower, A. G. (1951). Typhoid fever of short duration. Amer. F. med. Sci., 222, 174.

Baumgartner, E. A., and Olsen, H. H. (1920). Purulent typhoid meningitis. Arch. intern. Med., 25, 537.

Bayne-Jones, S. (1917). Typhoid meningitis: with report of a case. Amer. F. med. Sci., 154, 55.

Beene, M. L., Hansen, A. E., and Fulton, M. (1951). Salmonella meningitis. Recovery from meningitis due to Salmonella Sp. (type Montevideo), with consideration of the problems of Salmonella meningitis. Amer. F. Dis. Child., 82, 567.

Berman, S. E., Braun, K., and Rachmile'witz, M. (1945). Haemolytic anaemia in typhoid fever. Acta med. orient. (Tel-Aviv), 4, $17 \bar{j}$.

Blumer, G. (1895). Pyuria in typhoid fever. Fohns Hopk. Hosp. Rep., 5, 327.

Boquien, Y., and Grislain, J. P. (1949). Les formes méningees de la fièvre typhoide. Sem. Hôp. Paris, 25, 2411.

Campbell, J. M. (1966). A Bantu 'Typhoid Mary'. S. Afr. med.f., 40, 909.

Cole, R. I. (1904). Typhoid meningitis. Johns Hopk. Hosp. Rep., $12,379$.

Dérot, M., and Maschas, H. (1938). Méningite aiguë à bacille du groupe typhique. Bull. Soc. méd. Hôp. Paris, 54, 1678.

Drummond, J. (1943). Recent advances in the treatment of enteric fever. Clin. Proc., 2, 65.

Dukakis, P. S. (1927). Typhoid meningitis in a two months old baby. F. Amer. med. Ass., 89, 2257.

Dworecki, J. (1934). Typhusbazillen und meningenerkrankungen. Schweiz. Arch. Neurol. Psychiat., 33, 1.

Earle, A. M. (19j4). Some clinical aspects of typhoid fever in infancy. F. Pediat., 44, 681 .

Edge, W. (1950). Typhoid fever treated with chloramphenicol. Review of sixteen cases. Lancet, 1,710 .

Elia'xim, M. (1960). Electrocardiographic signs of pericarditis in typhoid fever. Amer. F. med. Sci., 239, 492.

El Ramli, A. H. (1950). Chloramphenicol in typhoid fever. Lancet, 1, 618.

(1953). Chloramphenicol in typhoid and paratyphoid fevers. New lines on treatment. ibid., 1, 927.

Feldman, N., and Selby, S. (1950). Chloromycetin therapy in typhoid fever in Bantu children. S. Afr. F. clin. Sci., 1, 149.

Friedman, A. (1954). An evaluation of chloramphenicol therapy in typhoid fever in children. Pediatrics, 14, 28.

Galloway, H., Clark, N. S., and Blackhall, M. (1966). Paediatric aspects of the Aberdeen typhoid outbreak. Arch. Dis. Childh., 41, 63.

Good, R. A., and Mackenzie, R. D. (1950). Chloramphenicol in typhoid fever. Lancet, 1, 611.
Griffith, J. P. C. (1912). Typhoid fever in infancy. An analysis of 75 cases. Arch. Pediat., 29, 565.

Gupta, A. K. (1942). A case of spontaneous dislocation of hip joint following typhoid arthritis. Indian med. Gaz., 77, 543.

Gurevitch, J. (1945). Typhoid bacilli in spinal fluid. Acta med. orient. (Tel-Aviv), 4, 314.

Hageman, P. O. (1938). Purulent typhoid meningitis with recovery. Amer. F. med. Sci., 195, 497.

Harries, E. H R., and Mitman, M. (1951). Clinical Practice in Infectious Diseases, 4th ed., p. 522. Livingstone, Edinburgh and London.

Henry, J. N., and Rosenberger, R. C. (1908). Purulent cerebrospinal me.uingitis caused by the typhoid bacillus, without the usual intestinal lesions of typhoid fever. Amer. F. med. Sci., 135, 240.

Herderschêe, D. (1927). Typhoid fever in children. Ned. T. Geneesk., 71, 2468. (Abstr. F. Amer. med. Ass., 89, 1012.)

Hersko, C., and Vardy, P. A. (1967). Haemolysis in typhoid fever in children with G-6-PD deficiency. Brit. med. F., 1, 214.

Hirsowitz, L., and Cassel, R. (1951). Thrombocyte counts in typhoid fever. S. Afr. med. $7 ., 25,303$.

Huckstep, R. L. (1962). Typhoid Fever and Other Salmonella Infections. Livingstone, Edinburgh and London.

Ikeme, A. C., and Anan, C. O. (1966). A clinical review of typhoid fever in Ibadan, Nigeria. f. trop. Med. Hyg., 69, 15.

Jaffe, N. (1966). Typhoid fever complicated by encephalopathy. Med. Proc., 12, 91.

Jáureguy, M. A. (1927). Typhoid meningitis. Arch. lat.-amer. Pediat., 21, 467.

Joshi, H. D. (1963). Complications, prognosis and relapse in typhoid fever. F. Indian med. Ass., 41, 67.

Kao, Y. E. (1948). Typhosus-meningitis in children. Report of a case. Chin. med. $., 66,83$.

Koplik, H. (1903). The occurrence and mortality of typhoid fever in infants and children. Arch. Pediat., 20, 335.

Landor, J. V. (1941). Typhoid fever: with special reference to the value of new antisera in therapy and eosinopenia in diagnosis. Trans. roy. Soc. trop. Med. Hyg., 35, 1.

Lantin, P. T., Gamboa, E. L., and Sadili, F. (1951). Studies on chloramphenicol in the treatment of typhoid fever. Amer. $\mathcal{F}$. med. Sci., 222, 285.

--, Geronimo, A., and Calilong, V. (1963). The problem of typhoid relapse. ibid., 245, 293.

, and Ignacio, P. (1929). Complications and fatality of typhoid fever among Filipinos. ibid., 178, 32.

- - and Morales, S. B. (1938). Unusual types of typhoid infection. f. Philipp. med. Ass., 18, 59.

Lavenson, R. S. (1908). Typhoid meningitis without other lesions. Univ. Pa med. Bull., 21, 55.

Le Riche, H., and Peacock, P. N. B. (1951). Typhoid fever in South Africa. Treatment of 215 cases without chloromycetin and 139 with chloromycetin (chloramphenicol). S. Afr. med. f., 25, 921.

Lien-Keng, K., and Odang, O. (1959). The bone marrow picture of typhoid fever in children. F. trop. Pediat., 5, 35.

Lozoya, S. J. (1948). Intestinal perforation and rupture of the gallbladder in children with typhoid. Amer. F. Dis. Child., 75, 832.

Mainzer, F. (1947). Electrocardiographic study of typhoid myocarditis. Brit. Heart $\mathcal{F} ., 9,145$.

Marie, P. (1884). Sclérose en plaques et maladies infectieuses. Progr. med. (Paris), 12, 287. (Quoted by Jennings, G. H. (1949). Protracted nervous complications of typhoid fever. Lancet, 2, 1218.)

Miarmion, D. E. (1952). The treatment of typhoid fever with chloramphe iicol. Trans. roy. Soc. trop. Med. Hyg., 46, 619.

McFadzean, A. J. S., and Choa, G. H. (1953). Haemolytic anaemia in typhoid fever. A report of six cases, together with the effect of chloramphenicol and A.C.T.H. Brit. med. F., 2, 360 .

Minchin, R. L. H. (1939). Clinical and prognostic factors in typhoid in India. Indian med. Gaz., 74, 591.

Minor, G. R., and White, M. L. (1946). Some unusual thoracic complications of typhoid and Salmonella infections. Ann. intern. Med., 24, 27.

Musoke, L. K. (1952). Typhoid fever in Mulago Hospital in 1949. E. Afr. med. F., 29, 209.

del Negro, G. (1962). Clinical considerations of typhoid fever in childhood: analysis of 60 cases. In Year Book of Pediatrics (1961-1963), p. 116. Ed. by S. S. Gellis. Year Book Publishers, Chicago. 
Osler, W. (1895a). Typhoid fever. In The Principles and Practice of Medicine, 2nd ed., p. 1. Young J. Pentland, Edinburgh and London.

- (1895b). Haemoglobinuria in typhoid fever. Fohns Hopk. Hosp. Rep., 5, 311. (Quoted by McFadzean, A. J. S., and Choa, G. H. (1953). Haemolytic anaemia in typhoid fever. A report of six cases, together with the effect of chloramphenicol and A.C.T.H. Brit. med. F., 2, 360.)

- (1906). Convulsions in typhoid fever. Practitioner, 76, 1.

- - and McCrae, T. (1920). Typhoid fever. In The Principles and Practice of Medicine, 9th ed., p. 1. D. Appleton, New York and London.

Patch, F. S. (1925). Typhoid infections of the kidney. f. Urol. (Baltimore), 14, 199.

Patel, J. C., Banker, D. D., and Modi, C. J. (1954). Typhoid fever. Indian med. Gaz., 89, 400.

Pathania, N. S., and Sachar, R. S. (1965). Typhoid and paratyphoid fevers in Panjab (India): a study of 340 cases. Amer. $\mathcal{F}$. trop. Med. Hyg., 14, 419.

Pohowalla, J. N. (1965). Typhoid fever in children. Indian $\mathcal{F}$. Pediat., 32, 253 and 285.

—, and Ghai, O. P. (1957). Typhoid encephalopathy in children. ibid., 24, 137.

Prabhu, M. G. (1955). Some observations in typhoid fevers. 7. Indian med. Ass., 25, 122.

Rachmilewitz, M., and Braun, K. (1948). Electrocardiographic changes in typhoid fever and their reversibility following niacin treatment. Amer. Heart f., 36, 284.

Rajoo, T. D. (1942). An analysis of 356 cases of enteric fever treated in the King Edward Memorial Hospital, Secunderabad, Deccan. Indian med. Gaz., 77, 395.

Rankin, A. L. K., and Grimble, A. S. (1950). Treatment of typhoid fever with chloramphenicol. Lancet, 1, 615.

Retief, F. P., and Hofmeyr, N. G. (1965). Acute haemolytic anaemia as a complication of typhoid fever. S. Afr. med.F., 39, 96.

Ripy, H. W. (1950). Typhoid fever in an infant complicated by typhoid meningitis: therapeutic failure with chloromycetin but response to aureomycin. F. Pediat., 36, 376.

Roger, H., and Gastaut, H. (1945). L'encéphalite vegétative dans la fièvre typhoïde. Presse méd., 53, 709.

Rolleston, J. D., and Ronaldson, G. W. (1940). Typhoid fever. In Acute Infectious Diseases, 3rd ed., p. 146. William Heinemann (Medical Books), London.

Rowland, H. A. K. (1961). The complications of typhoid fever. f. trop. Med. Hyg., 64, 143.

Ruggieri, P. A. (1961). Hemolytic anemia in typhoid fever. Delawere med. $\mathcal{F}$., 33, 77.

Schachter, M. (1954). Les encéphalopathies post-typhoïdiques chez l'enfant. Ann. paediat. (Basel), 183, 43.

Schweisgut, A. (1927). Zur Kenntnis der Meningitis typhosa. Klin. Wschr., 6, 215.

Scott, R. B., Banks, L. O., and Crawford, R. P. (1950). Typhoid fever in children. Arch. Pediat., 67, 224.

Sen, S. (1946). Neurological complications of typhoid fever. F. Indian med. Ass., 15, 364.

Smadel, J. E., Bailey, C. A., and Lewthwaite, R. (1950). Synthetic and fermentation type chloramphenicol (chloromycetin) in typhoid fever: prevention of relapses by adequate treatment. Ann. intern. Med., 33, 1.

—, Woodward, T. E., and Bailey, C. A. (1949). Relation of relapses in typhoid to duration of chloramphenicol therapy. 7. Amer. med. Ass., 141, 129.

Smith, C. E. G. (1951). Haemoglobinuria in typhoid fever treated with chloramphenicol. Lancet, $2,1020$.

Smith, E. B. (1911). Typhoid fever in childhood: an analysis of one hundred consecutive cases. Brit. 7. Child. Dis., 8, 390.

Smithies, F. (1907). Hemiplegia as a complication in typhoid fever. f. Amer. med. Ass., 49, 389.

Sood, S. C., and Taneja, P. N. (1961a). Typhoid fever. Clinical picture and diagnosis. Indian f. Child Hlth, 10, 69.

- and - (1961b). Typhoid fever. (Value of synthetic and naturally occurring corticosteroids.) ibid., 10, 271.

Stuart, B. M., and Pullen, R. L. (1946). Typhoid: clinical analysis of 360 cases. Arch. intern. Med., 78, 629.

Stuart, W. E. (1948). Typhoid meningitis. Brit. med. F., 2, 77.

Sulakhe, W. D. (1941). Some observations on enteric fevers. Indian med. Gaz., 76, 324.

Symmers, W. St. C., and Wilson, W. J. (1909). On three cases of cerebro-spinal meningitis, associated respectively with Bacillus anthracis, Bacillus typhosus, and Bacillus enteritidis (Gaertner) f. Path. Bact., 13, 251.

Thanawala, J. K. (1955). Observations on complications and treatment of enteric group of fevers. F. Indian med. Ass., 25, 125.

Top, F. H. (1947). Typhoid fever. In Communicable Diseases, 2nd ed., p. 674. C. V. Mosby, St. Louis.

Vaizey, J. M. (1959). Typhoid at Mulago. Analysis of cases in 1949 and 1957. E. Afr. med. F., 36, 65.

Watson, K. C. (1954). Chloramphenicol in typhoid fever: a review of 110 cases. Trans. roy. Soc. trop. Med. Hyg., 48, 526.

- (1955). A laboratory and clinical study of typhoid fever. M.D. Thesis, Aberdeen University.

(1957). The relapse state in typhoid fever treated with chloramphenicol. Amer. F. trop. Med. Hyg., 6, 72.

- (1958). Enteric fevers. In Diseases of Children in the Subtropics and Tropics. p. 589. Ed. by H. C. Trowell and D. B. Jelliffe. Edward Arnold, London.

(1967). Intravascular Salmonella typhi as a manifestation of the carrier state. Lancet, $2,332$.

Wieland, E. (1930). Encephalitis nach Typhus und nach Paratyphus B bei zwei Kleinkindern. Mschr. Kinderheilk., 47, 289.

Woodward, T. E., Smadel, J. E., and Ley, H. L., Jr. (1950). Chloramphenicol and other antibiotics in the treatment of typhoid fever and typhoid carriers. $f$. clin. Invest., 29, 87.

, - - , Green, R., and Mankikar, D. S. (1948). Preliminary report on the beneficial effect of chloromycetin in the treatment of typhoid fever. Ann. intern. Med., 29, 131.

- - and Parker, R. T. (1954). The therapy of typhoid fever. Med. Clin. N. Amer., 38, 577.

Wright, F. J. (1945). Haemoglobinuria in typhoid fever. E. Afr. med. ., $22,24$.

Zellweger, H., and Idriss, H. (1960). Encephalopathy in Salmonella infections. Amer. F. Dis. Child., 99, 770. 